\title{
PRAKTIK MEDIA SOSIAL PERANGI MEDIA KONVENSIONAL (TINJAUAN KOMUNIKASI POLITIK PILPRES INDONESIA 2019)
}

\author{
Oleh : \\ Patricia Robin ${ }^{1}$ \\ patrobin23@gmail.com \\ Dosen Program Studi Ilmu Komunikasi \\ Universitas Bunda Mulia, Kampus Serpong
}

\begin{abstract}
Abstrak
Politik memasuki ranah kehidupan manusia hingga ke tahap personal. Hal ini ditunjukkan dengan media sosial dalam kampanye politik yang menyerang individu, berakhir dengan preferensi atau pilihan politik warga negara. Para kandidat (aktor politik) memainkan pikiran dan waktu individu sehingga mengikuti apa yang mereka arahkan (memilih diri atau membenci kompetitor). Hal ini tidak mungkin terjadi tanpa andil dari komunikasi dan teknologi. Pilihan politik bukan lagi masalah hati, tetapi mana partai dan kandidat yang mampu mendekatkan diri dengan banyak janji. Pemilihan Presiden Amerika 2016 menjadi contoh keberhasilan media sosial dalam menentukan iklim dan pilihan politik. Hal ini kiranya juga terjadi di Indonesia, tepatnya pada Pemilihan Umum Presiden 2019. Dua kubu yang berkompetisi bukan sekedar menyatakan visi, tetapi mencari panggung dan muka di hadapan pendukung dengan harapan mendulang suara. Fakta yang terjadi, kemajuan teknologi tidak melulu diikuti dengan pengembangan diri individu. Maka yang kerap menjadi soal adalah konflik di ranah media sosial akhirnya berlanjut ke media massa konvensional hingga dunia nyata. Kedewasaan yang kiranya menjadi kunci keberhasilan dan eksistensi literasi politik hilang, dibutakan dengan pendapat dan argumentasi pribadi.
\end{abstract}

Kata Kunci : Kampanye Politik, Media Sosial, Pemilu 2019, filter bubble, Dunia Siber 


\section{PENDAHULUAN}

Politik memasuki ranah hidup manusia, bukan ketika menjadi makhluk sosial saja, melainkan sudah diinternalisasi menjadi pemikiran pribadi yang berujung pada pertunjukkan karakter diri seseorang. Hal ini begitu erat terasa ketika tibalah masa Pemilihan Umum, dimana masingmasing orang berlomba mengadu kepintaran, pengetahuan, isu bahkan sensasi tentang aktor-aktor politik yang sedang memperebutkan kursi. Esensi Pemilihan Umum yaitu pertarungan kandidat, akhirnya memiliki keseruan sendiri yaitu para pendukung dan pembenci kandidat militan yang berdebat pendapat satu sama lain.

Konflik dalam dunia politik memang tidak dapat dihindari. Sejak awal keberadaan politik sudah merupakan konflik karena dipastikan ada yang dipertentangkan dan diperjuangkan di sana. Perjuangan ini bisa menyangkut antar kelas, antar komunitas bahkan antar pribadi. Pemilihan Umum yang merupakan proses memilih orang untuk mengisi jabatan-jabatan politik tertentu merupakan ciri tersurat dari Negara Demokrasi. Proses ini memiliki tendensi konflik terbesar lantaran sudah jelas memiliki hasil "Pemenang" dan "Kalah".

Jabatan-jabatan yang diperebutkan dalam Pemilu terdiri dari tingkat teratas hingga tingkat terbawah, sebut saja dari
Presiden, Wakil Rakyat, hingga Kepala Daerah. Pemilu tidak berlangsung dalam waktu singkat dan sekali jalan, melainkan melalui proses pemilihan internal dari partai, persuasi kepada masyarakat dengan tujuan mendapatkan simpati yang berujung pada pemberian suara, hingga tibalah hari Pemilu dimana masyarakat bisa menggunakan hak pilih dan sesegera mungkin tercetuslah pemimpin yang menang pada periode tersebut.

Komunikasi politik merupakan proses komunikasi yang memiliki implikasi atau konsekuensi terhadap aktivitas politik. Dalam hal ini, pesan yang disampaikan dalam ranah ini memiliki bobot politik, dan menyasar anggota masyarakat yang dapat menggunakan hak suara dalam pemilihan. Dari semua proses yang dilalui, kampanye merupakan elemen yang paling menarik. Dalam bagian ini, para kandidat berlomba-lomba mencari pihak yang bisa memuluskan jalan memegang jabatan. Yang menjadi perbincangan adalah ketika jalan tersebut tidak dilalui atau dilakukan dengan baik, melainkan cara "jahat" tertentu yang pada intinya bertujuan melemahkan pihak lawan dan pihak lain yang bisa menghambat mencapai tujuan. Kampanye merupakan usaha untuk memengaruhi rakyat secara persuasif (tidak memaksa) dengan melakukan kegiatan retorika, hubungan 
publik, komunikasi massa, lobi dan lainnya (Cangara, 2016).

Dahulu keberadaan politik hanya dirasakan dan dilakukan oleh kaum elit yang benar terlibat dan menjadi bagian di dalamnya. Tetapi kini, masyarakat berlomba-lomba untuk masuk dalam pembahasan mengenai politik, bahkan terkadang menjadi sebegitu hebatnya seolah menjadi pengamat yang mampu memberikan pandangan "paling benar". Fenomena ini nyatanya tidak akan terjadi tanpa adanya campur tangan dari media sosial.

Salah satu media sosial yang menjadi sorotan adalah Instagram dengan total 800 juta pengguna. Fitur di Instagram memungkinkan penggunanya untuk mengunggah foto, teks, maupun video yang dapat dilihat jutaan orang. Masyarakat yang melihat unggahan tersebut dapat masuk dalam proses refleksi atas apa yang ia lihat dan menganggap bahwa unggahan itu sebagai realita (Davies, 2007).

Dirilis oleh We are Social (2018) menuliskan bahwa Instagram sebagai salah satu platform media sosial yang dipakai masyarakat global, termasuk Indonesia dengan total populasi mencapai 265 juta jiwa. Lebih dari separuh warga Indonesia adalah pengguna aktif media sosial $(124,8$ juta jiwa), dimana sebanyak 53 juta jiwa adalah pengguna aktif (We are Social,
2018). Yang menjadi ramai diberitakan terkait ragam cerita dan histori adalah Pemilu yang dilaksanakan pada April 2019. Dilaksanakan secara serentak, pemilu ini memiliki ragam kisah, baik sebelum, ketika pelaksanaan hingga pasca pengumuman Presiden terpilih untuk periode 5 tahun ke depan. Dua pasangan yang mendaftar ke Komisi Pemilihan Umum (KPU) pada 10 Agustus 2018 adalah yaitu Joko Widodo atau Jokowi dan Ma'ruf Amin, serta Prabowo Subianto dan Sandiaga Uno (Agus, 2018; Asril, 2018).

Memiliki posisi sebagai petahana yang notabene dianggap lebih unggul, ternyata perlawanan cukup keras juga dilakukan oleh Prabowo Subianto dan Sandiaga Uno. Mantan Komandan Pasukan Khusus (Kopassus) TNI periode 1995-1998 itu sudah melakukan pencalonan diri sebagai Presiden untuk ke4 kalinya. Kilas balik singkat yang peneliti sampaikan adalah Prabowo pertama kali mengajukan diri pada tahun 2004, melalui sistem konvensi di Partai Golkar. Setelah gagal melalui Partai Kuning berlogo pohon Beringin tersebut, ia mendirikan Partai sendiri yang dikenal dengan nama Partai Gerindra. Tepat satu tahun setelah pendirian Partai Gerindra yaitu tahun 2009, sosok yang pernah menjadi bagian dari Keluarga Cendana ini digandeng oleh Ketua Umum Partai Demokrasi Indonesia Perjuangan (PDI-P) Megawati 
Soekarnoputri sebagai calon wakil presiden.

Perjuangan tidak berhenti, selang 5 tahun kemudian, tepatnya ketika berhadapan dengan Joko Widodo dan Jusuf Kalla, Prabowo Subianto kembali memasuki pertarungan sebagai Presiden berpasangan dengan Ketua Umum Partai Amanat Nasional (PAN) Hatta Rajasa dalam Pilpres 2014, tapi kembali gagal (Lestari, 2014). Sebagai penutup perjuangan politiknya sebagai calon presiden, Prabowo Subianto kembali mencalonkan diri dan berpasangan dengan Sandiaga Uno yang saat itu masih menjabat sebagai Wakil Gubernur DKI Jakarta untuk Pilpres 2019.

Salah satu yang tidak bisa dilewatkan adalah bagaimana media sosial dimanfaatkan oleh dua pasang calon presiden dan wakil presiden. Media ini menjadi sarana pembentukan citra dan mampu menggantikan komunikasi tatap muka. Capres dan cawapres berhasil membangun koneksi dengan masyarakat yang tidak pernah mereka temui, hanya dengan mengatur informasi yang dibagikan ke mereka melalui media sosial. Masing-masing dari mereka memiliki akun instagram dengan keterangan sebagai berikut (Update Februari 2020):

\begin{tabular}{|l|l|l|l|l|}
\hline \multicolumn{1}{|c|}{ Tokoh } & \multicolumn{1}{|c|}{$\begin{array}{c}\text { Nama akun } \\
\text { Instagram }\end{array}$} & \multicolumn{2}{|c|}{$\begin{array}{c}\text { Followers \& } \\
\text { Following }\end{array}$} & Posts \\
\hline $\begin{array}{l}\text { Joko } \\
\text { Widodo }\end{array}$ & @jokowi & 28,4 juta & 0 & 1872 \\
\hline
\end{tabular}

\begin{tabular}{|l|l|l|l|l|}
\hline $\begin{array}{l}\text { KH. } \\
\text { Ma'ruf } \\
\text { Amin }\end{array}$ & @kyai_marufamin & 223.000 & 1 & 349 \\
\hline $\begin{array}{l}\text { Prabowo } \\
\text { Subianto }\end{array}$ & @prabowo & 5 juta & 1 & 395 \\
\hline $\begin{array}{l}\text { Sandiaga } \\
\text { Uno }\end{array}$ & @ sandiuno & 6.9 juta & 266 & 4468 \\
\hline
\end{tabular}

Tabel 1.1.

\section{Keterangan Instagram Kandidat Pemilu} 2019

Setiap pasangan memiliki kemampuan untuk membentuk citra untuk dirinya sendiri. Setiap individu yang mencalonkan diri memiliki keinginan dan kemampuan sendiri ingin dipandang seperti apa di masyarakat Indonesia. Dari sisi pasangan Joko Widodo atau Jokowi dan Ma'ruf Amin, banyak platform yang digunakan bukan hanya untuk memamerkan hasil kerja, melainkan juga "merespon" video viral yang secara langsung tak langsung ditujukan kepadanya. Keaktifan Presiden Joko Widodo dalam media sosial ditanggapi beragam oleh warga internet (warganet). Hampir di setiap unggahan, perdebatan terjadi, antara tudingan pencitraan dan dukungan

(https://www.cnnindonesia.com/nasional/2 0180323084239-32-285240/media-sosialjokowi-antara-pencitraan-dan-komunikasipublik).

Ikatan Cendikiawan Muslim SeIndonesia (ICMI) merilis hasil riset mengenai pandangan warganet di media sosial seputar Pilpres 2019. Berdasarkan hasil riset tersebut, pasangan Joko Widodo 
dan Ma'ruf Amin masih mendominasi tone positif tertinggi di media sosial hingga 67 persen, Sedangkan untuk pasangan Prabowo Subianto dan Sandiaga Uno, tone positif keduanya di media sosial adalah 59 persen (https://tirto.id/riset-media-icmipembicaraan-media-sosial-jokowi-lebihpositif-dlFe).

Bukan semata membandingkan, penelitian ini ingin memberikan gambaran menyeluruh mengenai bagaimana kemampuan calon presiden dan wakil presiden Indonesia dalam menggunakan media sosial sebagai sarana berkampanye. Apabila di media massa konvensional, ada penyaringan yang dilakukan oleh redaksi bahkan oleh lembaga pemerintah (seperti Komisi Penyiaran Indonesia), di media sosial para calon bebas menyampaikan apapun dan langsung mengenai sasaran yang menjadi followers-nya. Para kandidat memiliki ruang bebas tanpa filter untuk menyapa pendukung (atau pembenci mereka) hingga akhirnya berujung pada pengelolaan manajemen citra politik yang sesuai dengan kebutuhan dan keinginan dari kandidat. Media sosial adalah ranah "lepas" untuk mengunggah foto, maupun video, dilengkapi dengan teks sesuai sehingga bisa berdampak maksimal.

Peneliti menelisik jawaban mengenai bagaimana peranan media sosial dalam kampanye presiden di Indonesia. Media ini bukan semata ingin menunjukkan kapabilitas dan kredibilitas dari kandidat, melainkan kadang digunakan sebagai bentuk konfrontasi atau kontra dari pasangan lain. Masyarakat yang menjadi pengikut diajak untuk melihat ke dua sisi dari kandidat, bukan hanya mengutamakan atau mengedepankan kehebatan dari diri saja. Maka menjadi menarik untuk mengetahui peranan masyarakat dalam lingkup media sosial ini. Apakah mereka lantas menjadi penerima saja, atau justru juga berperan aktif dalam penyebaran dan pemaknaan terpaan media sosial tersebut.

\section{TINJAUAN TEORITIS}

\section{Komunikasi Politik dalam Media Sosial}

Politik kian menarik diperbincangkan oleh berbagai latar belakang dan kelas sosial dengan ragam intensitas dan persepsi yang berbeda. Komunikasipun semakin akrab dengan ragam konteks yang terjadi dalam kehidupan sehari-hari. Komunikasi politik pada akhirnya memiliki implikasi atau konsekuensi terhadap aktivitas politik. Pesan yang disampaikan dalam ranah ini memiliki bobot politik, dan menyasar anggota masyarakat yang dapat menggunakan hak suara dalam pemilihan. Bukan hanya dilakukan dalam lingkup komunikasi langsung tatap muka, komunikasi politik juga dominan dilakukan melalui media massa khususnya 
audio visual. Melalui media massa tersebut, para politisi biasanya mengusung isu publik dan menawarkan beragam kebijakan publik dalam sejumlah arena kampanye politik (Cangara, 2016).

Beragam kegiatan politik, sosok serta latar belakang sosial budaya ditampilkan secara wajar melalui program tayangan berita, feature maupun progamprogram yang lain. Komunikasi politik di era dominasi media audio visual ini melahirkan sejumlah elit politik generasi baru. Dalam arena sistem politik demokratis, elit politik yang kian canggih memanfaatkan media massa sebagai arena membangun citra politik kepada publik (Ahmad, 2012:70).

Kehadiran rezim politik dengan watak dan performance tertentu memperkuat persepsi masing-masing manusia terhadap dunia politik. Ada saja yang beranggapan bahwa politik identik dengan manipulasi, kecurangan, dan kejahatan. Tetapi ada pula yang beranggapan bahwa politik sejalan dengan perjuangan nilai bersama dan kepentingan publik demi memiliki derajat mulia dalam sejarah kehidupan manusia (Ahmad, 2012:42).

McNair, 2003 menyampaikan tiga hal utama yang wajib diperhatikan oleh aktor politik ketika melakukan komunikasi politik. Hal ini yang kiranya digunakan oleh para kandidat atau pelaku politik ketika berhubungan dengan masyarakat yang menjadi target utama, ataupun dengan sesama pesaing yang berujung pada mendapatkan simpati dari audiens. Yang menjadi fokus utama menurut McNair adalah segala bentuk komunikasi oleh politisi dan aktor politik lainnya digunakan demi mencapai tujuan tertentu. Sebuah komunikasi politik sebaiknya tidak hanya berfokus pada pesan verbal atau pernyataan tertulis, melainkan juga nonverbal atau bahasa tubuh (gaya berpakaian, gaya rambut, serta cara berjalan, dan lainnya); Ke-dua, komunikasi dilakukan dengan siapa saja, bahkan dengan pihak yang dianggap aktor non-politik (individu dengan hak pilih maupun kolumnis, kepada aktor politik); Ke-tiga, komunikasi tentang aktor politik serta aktivitas yang dilakukan dimuat di berita maupun platform media lainnya, termasuk media sosial termasuk dalam bentuk komunikasi politik. Hal ini semakin maksimal terasa lantaran ketidakmampuan kandidat untuk bertatap muka dengan masyarakat di seluruh daerah atau tempat. Keberadaan media sosial mampu mendekatkan kandidat dengan pendukungnya. Yang menjadi prioritas utama adalah kemampuan menempatkan sosok yang bisa mengatur pembuatan pesan di media sosial tersebut sehingga tepat dalam segi konten hingga waktu penyebarannya 
(Stanyer, 2008; Filimonov et al, 2016; Simunjak, 2017).

Konteks komunikasi politik yang diuraikan di sini berada dalam lingkup negara yang demokratis. Proses penggunaan hak suara dilakukan tanpa adanya paksaan sama sekali, melainkan atas terciptanya kesepahaman. Seperti yang diungkapkan Stanyer (2008), Filimonov et al (2016), dan Simunjak (2017), media baru memberi ruang bagi politisi untuk menampilkan diri mereka tanpa perlu takut lagi ada filter yang dilakukan media berita. Indrananto menuturkan bahwa demokrasi memusatkan perhatian pada pentingnya peran setiap individu. Proses politik yang berlaku mensyaratkan bahwa setiap individu bertindak secara kolektif untuk menentukan siapa yang berhak memimpin mereka (Indrananto, 2002:31).

Keberadaan media sosial melepaskan stigma bahwa kandidat memegang sepenuhnya kontrol pemberitaan. Dalam satu sisi memang benar bahwa kontrol tersebut ada, yaitu terhadap unggahan konten di media massa, dimana peran wartawan menjadi begitu minimal sampai tidak ada sama sekali, tetapi kontrol selanjutnya berada dalam tangan audiens yang bisa menentukan, jenis unggahan apa yang akan dilihat, untuk kemudian diterima dan dimaknai atau dijadikan perbincangan dalam keseharian.

Menaikkan sebuah isu ke dalam media massa untuk dapat dilihat oleh masyarakat pada zaman dahulu merupakan pekerjaan wartawan. Berita dan peristiwa yang layak menjadi perbincangan adalah bila memiliki nilai berita. Peliputan hingga pengelolaan membuat berita sampai ke segmentasi yang dituju, walau belum mencapai $100 \%$. Pengeluaran tenaga, waktu serta materi dilakukan secara besarbesaran oleh media massa konvensional, tetapi hal ini tidak terasa sama sekali dalam penggunaan media sosial. Kandidat dapat menghemat pengeluaran, karena media sosial memungkinkan promosi diri secara gratis (Stanyer, 2008).

\section{Media Sosial dan Dunia Politik}

Dunia politik semakin berkembang dengan keberadaan dari internet, khususnya media sosial. Semakin banyak kata dan pengertian baru yang digunakan, tetapi tidak diimbangi dengan pengetahuan dan kemampuan menggunakannya. Peneliti akan memaparkan satu persatu dengan uraian sebagai berikut.

Kata pertama adalah "Populisme". Dalam KBBI Online, populisme diartikan sebagai paham yang mengakui dan menjunjung tinggi hak, kearifan, dan keutamaan rakyat kecil. Hal ini seringkali didengar ketika para kandidat 
melaksanakan aksi persuasi untuk mendapatkan suara. Konsep politik ini "seakan" mengutamakan suara dan kepentingan rakyat ketika kampanye ataupun bermedia sosial atau debat, bahkan pemilihan nonverbal yang akan disajikan ke muka umum. Padahal nyatanya hal itu hanya untuk menarik simpati semata. Mereka menciptakan diri sebagai sosok pemimpin karismatik dan akhirnya pengikut akan mengalami ketergantungan terhadap sosoknya.

Populisme definisikan sebagai "ideologi" yang membagi masyarakat ke dalam dua kelompok bertentangan antara "orang-orang murni - masyarakat umum" dan "para elit". Walaupun ada pertentangan ini, jurang dan keresahankeresahan yang berkembang dinikmati, sehingga menjadi isu yang dibawa kaum populis untuk menyatukan dukungan masyarakat. Mobilisasi massa dengan mudah untuk mencapai tujuannya. (Mudde \& Kaltwasser, 2017).

Terdapat pemimpin populis yang menyatakan bahwa gagasan "rakyat sebagai kedaulatan" dan menjadikan bahwa demokrasi terbaik pasti berasal dari badan kolektif. Selama ada massa yang bersatu dan saling mendukung, dengan mudah mereka bisa melawan musuh bersama yaitu elit partai politik dan pemerintah korup. Pengerahan ini biasanya berjalan seiring dengan kritik-kritik terhadap musuh bersama tersebut.

Keberadaan dari internet juga menciptakan fenomena tersendiri yang begitu unik dan bisa terjadi karena pertemuan bermanfaat antara algoritma dan teknologi. Sebagai contoh, ketika kita memiliki ketertarikan tersendiri tentang isu aksi demonstrasi, maka yang akan muncul selanjutnya dalam wall Facebook atau feed Instagram adalah mengenai demonstrasi tersebut. Hal ini juga berlaku ketika seseorang lebih menyukai cabang olahraga tertentu. Maka tanpa perlu mencari penjelasan atau tautan yang selanjutnya, secara otomatis akan terpampang informasi (tulisan/ foto/ video) terkait hal tersebut.

Chief Executive Google, Lary Page menyatakan bahwa mesin pencari utama mengerti dengan tepat apa yang dimaksud, dan mampu mengembalikan apa yang diinginkan. Hal ini disambut positif oleh aktivis internet, Eli Pariser yang melihat adanya kejanggalan berbahaya dari sistem algoritma. Sebuah gelembung besar tercipta dan individu terkungkung di dalamnya. Ia akan melihat sebuah berita dari sudut pandangnya semata dan menafikan atau tidak peduli dengan keberadaan pendapat lain. Isolasi ini bukan terjadi secara fisik, melainkan lebih ke arah isolasi intelektual. Pendefinisian 
dunia, dimungkinkan hanya dari satu sudut pandang saja.

Filter bubble adalah kesalahan konsensus akibat keseragaman informasi yang diperoleh. Dunia dibangun dari kesamaan atau familiaritas saja, tdak ada hal yag baru yang ingin atau mau dipelajari. Individu yang merasakan dampak ini akan merasa memiliki orang yang senasib atau setipe dengan dirinya. Akhirnya kepercayaan diri muncul karena merasa memiliki teman. Yang berbahaya adalah ketika selanjutnya pandangan ini dianggap sebagai wujud suara mayoritas.

Keberadaan hoax yang merajalela adalah dampak buruk dari filter bubble. Pemberian judul bombastis adalah praktik realnya. Sangat disayangkan manakala warganet yang sudah memiliki platform mencari berita sendiri terbiasa hanya membaca judul tanpa mengklik konten. Data menyebut, 59 persen link berita yang dibagikan di media sosial tidak benarbenar diklik sama sekali.

Praktik filter bubble bukan wujud demokrasi yang baik. Ketika tidak bisa diakomodir dengan maksimal, yang terjadi adalah penutupan diri. Seseorang yang dicekoki informasi tentang buruknya suatu paham atau ekstrimis tertentu, tidak dipungkiri akan terbawa dan akhirnya mengingkari eksistensi gagasan lain. Kecenderungan selanjutnya adalah pemusatan pemikiran dan fanatisme. Hal itu akan merujuk pada individu-individu yang merasa pemahamannya antikritik.

Dilansir dari Tirto.id, kecenderungan masyarakat Indonesia adalah aktif di media sosial. Hal ini ditunjukkan dengan empat dari tujuh orang aktif dalam mencari dan menggunakan media ini sebagai sumber berita dan pengetahuan. Menjadi ironis ketika tidak semua orang mengetahui dan menyadari adanya filtter bubble yang identik dengan algoritma. Terdapat cara yang dilakukan oleh salah satu media sosial yaitu Facebook, yaitu usaha untuk tetap merealisasikan jurnalisme. Usaha ini adalah wujud pencegahan supaya setiap orang tidak sembarangan menyebar konten yang dibacanya dari sumber yang belum tentu kredibel. Walaupun belum berjalan maksimal, yang perlu diingat adalah pengguna media sosial berada dalam gelembung filter besar yang selama ini tak kasat mata dan bisa membuat orang melihat hanya dengan "kacamata kuda".

\section{METODE PENELITIAN}

Pemilihan Umum adalah ranah politik yang menjadi ajang ekspresi sekaligus eksistensi partai sekaligus kandidat yang akan memperebutkan sebuah kursi atau jabatan. Dalam hal ini yang peneliti soroti adalah kampanye politik yang dilakukan oleh 2 pasangan calon presiden pada Pemilu 2019. Apabila dirunut, keberadaan 
politik sudah dipastikan adalah wujud konflik. Lantas apa yang istimewa?

Dalam penelitian ini, peneliti akan mengkonstruksi secara detail dan mendalam mengenai konflik politik yang terjadi dalam kampanye, yang terjadi dari sisi pendukung, sekaligus dua pihak yang berseteru yaitu Joko Widodo dan Prabowo Subianto.

Peneliti menggunakan pendekatan kualitatif yang merupakan multi metode dalam fokus penelitian. Penelitian ini dilakukan untuk mencari jawaban dari bagaimana pengalaman sosial diciptakan dan memberikan makna. Proses interpretasi pada kondisi subjek alamiah diutamakan di sini, berhubungan juga dengan kenyataan atau fakta konstruk sosial. Kedekatan antara peneliti dan masalah yang diteliti terjadi. (Denzin \& Lincoln, 1994).

Dua jenis data yang digunakan oleh peneliti, antara lain:

\section{Data primer}

Yaitu data yang diperoleh langsung dari objek yang akan diteliti (narasumber) (Suyanto dan Sutinah, 2007: 55). Dalam penelitian ini, adalah rekam jejak kampanye yang dilakukan oleh 2 pasangan calon presiden.

\section{Data Sekunder}

Yaitu data yang diperoleh secara tidak langsung melalui media perantara atau digunakan oleh lembaga lainnya yang bukan merupakan pengolahnya, tetapi dapat dimanfaatkan dalam suatu penelitian tertentu (Ruslan, 2006:138). Data sekunder ini didapatkan peneliti dari buku- buku, jurnal, internet yang terkait masalah yang diteliti.

\section{HASIL DAN PEMBAHASAN}

Penelitian ini berfokus pada keberadaan media sosial dalam hubungannya dengan Pemilihan Presiden 2019 di Indonesia dengan calon presiden yaitu Joko Widodo dan Ma'ruf Amin, berhadapan dengan Prabowo Subianto dan Sandiaga Uno. Pemilu ini digadang sebagai Pemilu paling brutal karena menancapkan luka dan duka yang dalam bagi banyak pihak. Pertarungan ini bukan semata memerebutkan sebuah posisi atau jabatan, tetapi lebih ke agenda mempertahankan gengsi dan prestis. Bila dahulu setelah Pemilu berakhir, keluarga kembali menjadi keluarga, teman pun kembali akrab, sekarang hal ini berbeda. Sentimen-sentimen politik dalam media sosial seakan sudah mendarah daging dan perpecahan akibat perbedaan pilihan politik sukar diperbaiki.

Pemilu 2019 memiliki nilai berita tinggi karena derajatnya massif, dekat dan penting. Dua kandidat pasangan yang mendaftar ke Komisi Pemilihan Umum (KPU) pada 10 Agustus 2018 bertarung begitu gencar pada Pemilihan Umum 
2019. Bukan saja beradu ide, gagasan atau terobosan, ada suatu kebaruan ketika media sosial mengambil peran digunakan sebagai alat menjaring suara. Suatu ruang publik baru yang kaya akan data (Agus, 2018; Asril, 2018).

Dalam perjalanan penggunaan media sosial, keberadaannya diibaratkan sebagai seorang gembala yang mengarahkan kawanan ternak yang ada di depannya. Media sosial menjadi sebuah alat yang bisa menggerakkan, mengarahkan bahkan memanipulasi warganet yang berada di dalamnya. Apabila dahulu di dalam dunia televisi kita mengenal agenda setting, ternyata di dunia internet atau online, hal ini juga terjadi walau tidak dalam lingkup luas. Yang paling mudah dirasakan adalah ketika hari pelaksanaan Pemilu.

Bila dahulu, pilihan politik adalah hal yang privat dan RAHASIA, hanya boleh diketahui oleh diri sendiri, kini hal itu sudah bergeser. Ruang personal dimana hanya dimiliki oleh diri sendiri sudah hilang berganti dengan konsumsi publik. Seseorang yang akan memilih bisa "diganggu" keteguhannya bahkan sebelum masuk ke dalam bilik suara. Ketentuan tidak boleh membawa ponsel ke dalam bilik suara kiranya masih ada. Apabila tidak, bisa saja yang terjadi adalah ruang dalam bilik suara menjadi ajang selfie.

Kemampuan media sosial menjadi pengatur "Warganya" juga didukung oleh kehebatan dalam membentuk dan membangun sebuah isu di dunia maya. Ketika rakyat merasa mereka memilih atas dasar kehendak bebas atau freewill diri sendiri, fakta yang terjadi sebenarnya adalah bukan. Rakyat memilih atas dasar bentukan dan arahan. Unsur filter bubble kembali terkuak di sini.

Ketika kita mencari sebuah berita atau informasi mengenai seseorang, sebut saja salah satu kandidat presiden, jejak digital kita akan meninggalkan bekas pencarian tersebut. Maka ketika membuka situs sejenis atau berbeda lainnya, warganet akan diarahkan pada subjek atau pembahasan berita sejenis. Mereka yang tidak tau mengenai "gelembung", cenderung akan menganggap ini adalah kebetulan. "Dicekoki" oleh berita yang sama terus menerus, kepercayaan audiens akan terbentuk bahwa kandidat tersebut memang yang paling mengerti. Jargon "Atas nama Rakyat" atau "Dari, Oleh, dan Untuk Rakyat" adalah wujud praktik Populisme dilakukan di Indonesia. Pengutamaan peran rakyat sebagai puncak kepemimpinan tertinggi dimaksimalkan di sini. Hal ini merujuk pada praktik lain yang bernafaskan kebebasan berekspresi dari kandidat.

Dalam media massa konvensional seperti televisi dan koran, pemilihan berita yang akan diangkat sangat bergantung pada keputusan dari redaksi. Di sini juga 
eksklusifitas menjadi nihil karena semua media akan memiliki rujukan peristiwa dan kejadian yang sama. Hal ini tidak bisa menafikan nilai berita yang dominan dalam setiap praktik jurnalistik. Nilai berita yang harus ada, minimal mengandung unsur kebaruan, ketermukaan, dan independen atau berimbang.

Menjadi begitu berat untuk memasukkan isu atau kegiatan yang standard menjadi konsumsi audiens media massa. Maka di sinilah media sosial menjadi platform yang tepat. Setiap unggahan di media sosial sudah diatur sedemikian rupa sehingga disukai dan cocok dipandang oleh socmed lovers. Dalam penggunaan media sosial, kandidat akan merasakan keuntungan dari segi pengeluaran, karena publikasi dan publisitas yang berujung pada citra diri dan promosi diri dapat dilakukan secara gratis.

Dalam berita iklan, kandidat membayar sejumlah uang agar dapat tampil dalam bingkai yang dibentuk oleh media massa yang bersangkutan. Pencarian simpati masyarakat yang berujung pada suara yang diberikan ini digambarkan sebagai berikut. Aktor politik memiliki konsep yang dituangkan dalam bentuk cerita atau kegiatan yang ditayangkan atau dimuat di media massa. Sang aktor politik membayar sejumlah uang agar dapat tampil di media massa, baik cetak ataupun elektronik. Bukan nominal sedikit yang harus dikeluarkan, tetapi tidak sebanding dengan hasil yang dicapai belum tentu tepat sasaran. "Tembakan" ke audiens ini kurang spesifik sehingga tidak menyentuh sama sekali (Stanyer, 2008).

Penggunaan Instagram sebagai media politik adalah untuk menyajikan yang tidak mendapat tempat di media massa. Dibagi menjadi empat tugas pokok, yaitu penyiaran pesan, mobilisasi massa, mengelola citra kandidat atau partai, melengkapi materi kampanye (Filomonov et al, 2016).

Pemilu 2019 adalah wujud persaingan dan pertentangan dua kubu yang berseberangan. Tetapi yang penting dicatat bahwa bukan calon presiden melawan calon presiden yang sedang "bertanding" di sini, melainkan "presiden petahana" dengan calon presiden. Joko Widodo sebagai Presiden 2014 - 2019 memilliki keuntungan dan kelebihan dalam Pemilu ini. Bagaimana tidak? Ia memiliki data yang dibutuhkan untuk menjawab setiap pertanyaan debat, sama halnya memiliki akses melihat dan terjung ke lapangan untuk survey ataupun "blusukan". Maka ketika dihadapakan satu sama lain dalam ajang debat ataupun menjawab pertanyaan-pertanyaan bentukan dari 
media massa, Joko Widodo terkesan lebih menguasai panggung.

Peneliti membahas mundur pertarungan pada Pemilu 2014, dimana sosok "bertarung" juga adalah sosok Prabowo melawan Joko Widodo (bukan sosok petahana). Yang membedakan adalah Wakil Presiden masing-masing, juga "senjata" kampanye yang digunakan. Dalam Periode I, Joko Widodo sudah mengoptimalkan media terbarukan yaitu media sosial dengan merekrut tim atau Sumber Daya Manusia yang menjadi konsultan mumpuni. "Serangan" ini dilakukan secara perlahan namun pasti karena juga melibatkan keberadan public figure yang sudah terkenal dan memilih pihak. Sebut saja group band legendaris, Slank.

Berbeda dengan Joko Widodo, Prabowo Subianto masih dengan gaya konservatif atau gaya kampanye lama dengan melakukan "penyerangan" langsung bertemu dengan warga. Hal ini kiranya efektif ketika waktu kampanye panjang dan memungkinkan untuk bertegur sapa. Tetapi dengan jumlah penduduk dan besarnya wilayah Indonesia, langkah ini akhirnya dirasa menjadi kurang tepat guna. Rendahnya suara Prabowo dalam Pemilu 2014 tidak dipungkiri karena bentukan kisah dan cerita lanjutan terkait gerakan aksi massa yang sempat membuah kekisruhan di
Indonesia. Prabowo diasumsikan sebagai "dalang" hal tersebut, walau sampai sekarang belum ada pembuktian.

Berlanjut pada Pemilu 2019, dimana kekuatan menggunakan media sosial sudah berimbang. Gaya kampanye sudah sama, yaitu memaksimalkan keberadan media sosial.Prabowo memiliki kelebihan dimana akun yang menjadi pendukungnya adalah mereka yang real atau benar, sementara dari tim petahana, terdeteksi bahwa pendukung tidak sepenuhnya manusia, melainkan dibantu oleh "robot-robot". Hal ini sebenarnya bila ditelisik lebih jauh, merupakan wujud kekecewaan dari mereka yang "sakit hati" dengan kepemimpinan Joko Widod di Periode I. Banyak janji yang tidak terpenuhi, bahkan muncul banyak kebijakan yang "ngawur" dan tak berujung.

Kemenangan Joko Widodo adalah cermin dari beberapa hal. Yang utama, ia adalah penguasa, maka cenderung imbang dalam hal konteks sosial; Kedua, Joko Widodo mampu "menciptakan" kawan dan lawan secara langsung dan sekaligus. Ia memiliki infrastruktur. Infrastruktrur di sini bukan dalam hal pembangunan jalan raya atau moda transportasi umum, melainkan lebih jauh lebih ke kemampuan melahirkan infrastruktur politik sendiri. Sebagai penguasa, ia bisa merangkul dan membuang partai dan sosok yang ia mau jadikan teman atau musuh. Dan secara 
sadar, Prabowo adalah wujud bentukan "kompetitor politik" yang ia bentuk. Sosok Prabowo memang gahar dan dominan, tetapi secara probabilitas keterpilihan politik, ia cenderung minim. Yang membuat ia ada dan memperoleh suara yang cukup banyak adalah sosok Sandiaga Uno.

\section{PENUTUP}

Membahas mengenai Pemilihan Presiden Indonesia pada periode sebelumnya. Keberadaan Susilo Bambang Yudhoyono (SBY) adalah sosok baru dalam dunia politik saat itu. Ia mampu membawa nuansa intelektual sangat besar dan ke puncak kepemimpinan, menggantikan sifat ke-ibu-an Megawati di periode sebelumnya. Tetapi, 2 periode SBY selama 10 tahun dirasa cukup karena akhirnya ia juga tergantikan oleh sosok baru yaitu Joko Widodo yang lebih santai, merakyat dan terkenal dengan jargon "kerja, kerja, kerja".

Kemenangan Joko Widodo bukan berarti angin segar selamanya akan berpihak pada kubu Partai Politik PDI Perjuangan. Titik jenuh akan ada. Sebenarnya hal ini sudah mulai terasa ketika Prabowo mendulang cukup banyak suara di Pemilu 2019. Bukan kehebatannya yang dilirik oleh rakyat dan juga partai pendukung, melainkan lebih besar porsi sosok Sandiaga Uno yang mencuri perhatian dan suara rakyat.

Sandi adalah sosok yang muda, berpendidikan, berperawakan menarik dan wibawa. Berasal dari praktisi bisnis yang baru-baru ini saja masuk ke dunia politik, Sandi bahkan digadang bisa menjadi Calon Presiden 2024. Namanya bukan baru pertama digadang demikian. Kesempatan itu memang benar terus ada, tetapi lawan yang dihadapi juga tidak sepele. Sebut saja Anies Baswedan, Erick Thohir dan Ridwan Kamil dirasa menjadi sosok yang juga kuat. Belum lagi Partai Demokrat yang akan terus melancarkan Agus Harimurti Yudhoyono (AHY) sebagai kandidat, melawan juga Ganjar Pranowo yang merupakan produk dari PDIP.

Sebagai penutup mengenai pembahasan kampanye politik ini, dipastikan bahwa media sosial memegang peranan penting dalam menentukan langkah politik seorang individu ketika akan memilih kandidat sebagai pemimpinnya. Gaya komunikasi yang dilakukan juga kian berkembang, dari dahulu yang hanya membahas isu general saja, lantaran penayangan di media massa konvensional, kini beralih menjadi pembahasan hal yang lebih sederhana tetapi penayangan di media sosial. Masyarakat tidak bisa memilih siapa yang akan maju sebagai kandidat. Tetapi masyarakat dapat menentukan kriteria 
pemimpin seperti apa yang mengena di hati.

\section{DAFTAR PUSTAKA}

Ahmad, Nyarwi. 2012. Manajemen

Komunikasi Politik dan Marketing

Politik - Sejarah, Perspektif, dan

Perkembangan Riset. Yogyakarta:

Penerbit Pustaka Zaman.

Bryman, A. 2016. Social Research

Methods. 5ed. Oxford: Oxford

University Press.

Cangara, H. 2016. Komunikasi Politik:

Konsep, Teori, dan Praktik. Edisi

5. Jakarta: Penerbit Rajawali Pers.

Cogburn, D. L. dan Espinoza-Vasquez, F. 2011. From Networked Nominee to Networked Nation: Examining the impact of Web 2.0 and Social Media on Political Participation and Civic Engagement in the 2008 Obama Campaign, Journal of Political Marketing, 10(2), hlm. 189-213.

Corner, J. dan Pels, D. 2003.

'Introduction: the re-styling of politics', in Media and the Restyling of Politics, eds J. Corner dan D. Pels, London: Sage, hlm 6784.

Davies, J. 2007. Display, Identity, and the Everyday: Self-presentation through online image sharing, Journal of
Cultural Politics Education, 28(4), hlm. 549-564.

Denton, Robert E. 2017. The 2016 US

Presidential Campaign. USA:

Virginia Tech.

Denzin, N. K, \& Lincoln, Y. S. 1994. Handbook of Qualitative Research. California: Sage Publications, Inc.

Dinh, Tranh Van. 1987. Communication and Diplomacy in Changing World. Michigan University: Ablex Pub Corp.

Eriyanto. 2009. Analisis Wacana: Pengantar Analisis Teks Media. Yogyakarta: Penerbit LkiS.

Firmanzah. 2007. Marketing Politik Antara Pemahaman dan Realitas. Jakarta: Yayasan Obor Indonesia.

Giansante, Gianluca. 2015. Online Political Communication. New York: Springer Cham Heidelberg.

Goodhart, C. \& Lastra, R., 2017. Populism and central bank independence. LSE Research Online, pp. 1-19. Indrananto, C. 2012. Dramaturgi dalam Komunikasi Politik Walikota Solo Joko Widodo, Jurnal Komunikasi Indonesia, 1(2), hlm. 29-38.

Leftwich, Adrian. 2004. What is Politics The Activity and its Study Polity. Cambridge: Polity Press Ltd. Littlejohn, Stephen W. dan Foss, Karen A. 2009. Theories of Human Communication. Terjemahan 
Mohammad Yusuf Hamdan.

Jakarta: Penerbit Salemba

Humanika.

Lucas, Stephen E. 2012. The Art of Public

Speaking. New York: McGraw

Hill.

McNair, B. 2003. An Introduction to

Political Communication.

Routledge London dan New York.

Moleong, Lexy J. 2009. Metodologi

Penelitian Kualitatif. Bandung:

Remaja Rosda Karya.

Morrisan. 2014. Teori Komunikasi:

Individu Hingga Massa. Jakarta:

Kencana Prenadamedia Group.

Mudde, C. \& Kaltwasser, C. R., 2017.

Populism: A Very Short

Introduction. New York: Oxford

University Press.

Mulyana, D. 2004. Menimbang Iklan

Politik di Media Massa Menjelang

Pemilihan Presiden. MediaTor,

5(1), hlm. 75-81. . 2007. Ilmu Komunikasi Suatu

Pengantar. Bandung: Remaja

Rosda Karya.

Nursal, Adman. 2004 Political Marketing

Strategt Memenangkan Pemilu

Sebuah Pendekatan Baru

Kampanye Pemilihan DPR DPD

Presiden Jakarta: Gramedia

Pustaka Utama.
Patrut, Bogdan \& Monica Patrut. 2014.

Social Media in Politics. New

York: Springer Cham Heidelberg.

Simunjak, M. 2017. Political Impression

Management Through Direct and

Indirect Mediated Communication:

The 2014/2015 Croatian

Presidential Elections, Drustvena

Istrazivanja, 26(4), hlm. 539-560.

West, Turner \& Lynn H. Turner. 2007.

Pengantar Teori Komunikasi,

Analisis dan Aplikasi. Buku 2.

Salemba Humanika: Jakarta.

Watson, Adam. 1982. Diplomacy: The

Dialogue Between State. Methuen.

Ch.1.

http://kamusbahasaindonesia.org/kampany e $(29 / 12 / 2019,14: 53$ WIB).

https://nasional.kompas.com/read/2017/01/ 15/16143761/ancaman.gerakan.pop $\underline{\text { ulis.terhadap.demokrasi.di.indonesi }}$ a $(30 / 12 / 2019,18: 45$ WIB $)$.

https://kbbi.web.id/populisme (30/12/2019, 18:50 WIB).

http://www.balairungpress.com/2018/05/m enyelisik-hubungan-populismedan-demokrasi/ (30/12/2019, 19:00 WIB).

https://tirto.id/filter-bubble-sisi-gelapalgoritma-media-sosial-cwSU (02/01/2020, 06:50 WIB). 
Silvanus Alvin - Komunika Jurnal

(19/01/2020, 17:34 WIB).

Dakwah Komunikasi

Jakob Svensson

Manajemen Citra Politik Prabowo

Negotiating the Political Self on

Subianto Dan Sandiaga Uno

Melalui Akun@Prabowo Dan

Social Media Platforms (An In-

@ Sandiuno

Depth Study of Image-Management

http://ejournal.iainpurwokerto.ac.id

/index.php/komunika/article/view/2

$\underline{538}$

in an Election-Campaign in a

Multi-Party Democracy)

http://www.diva-

(03/01/2020, 08:12 WIB).

portal.org/smash/record.jsf?pid=div

$\underline{\text { a2\%3A676539\&dswid }=-9305}$

(23/01/2020, 18:45 WIB).

Rahayu Ramadani dan Mifda Hilmiyah-

IAIN Pare pare

Pembentukan Citra Politik di

Media Sosial Twitter

Http://ejurnal.iainpare.ac.id/index.p

hp/komunida/article/download/112

$\underline{6 / 641}$

(06/01/2020, 16:56 WIB).

SHIRLY ISTIQOMAH -Universitas

Muhammadiyah Malang

Kampanye Politik Cyber Media

Sebagai Salah Satu Faktor yang

Mempengaruhi Kemenangan

Obama dalam Pemilu Amerika"

http://eprints.umm.ac.id/31325/

(08/01/2020, 19:15 WIB).

Călin Gurău \& Nawel Ayadi

Political communication

management: The strategy of the

two main candidates during

the 2007 French presidential

elections

https://ideas.repec.org/p/hal/journl/

halshs-00738197.html 